\title{
PENGARUH STATUS SOSIAL EKONOMI DAN PENDIDIKAN PENGELOLAAN KEUANGAN DI KELUARGA TERHADAP LITERASI KEUANGAN SISWA SMK NEGERI 1 SURABAYA
}

\author{
Romadoni, Pascasarjana Unesa \\ romadhoni_s@yahoo.co.id
}

\begin{abstract}
ABSTRAK
Penelitian ini bertujuan untuk mengetahui pengaruh status sosial ekonomi dan pendidikan pengelolaan keuangan di keluarga terhadap literasi keuangan di SMK Negeri 1 Surabaya tahun ajaran 2013-2014. Populasi penelitian sejumlah 197 siswa. Sampel sebanyak 132 siswa yang diambil dengan menggunakan teknik random sampling. Data diambil menggunakan kuesioner dan metode dokumentasi. Metode analisis dalam penelitian adalah regresi linier berganda. Hasil penelitian menunjukkan bahwa status sosial ekonomi orang tua secara langsung mempengaruhi literasi keuangan, pendidikan pengelolaan keuangan di keluarga berpengaruh terhadap literasi keuangan dan status sosial ekonomi dan pendidikan pengelolaan keuangan di keluarga secara bersama-sama berpengaruh langsung signifikan terhadap literasi keuangan.
\end{abstract}

Kata Kunci : Status sosial ekonomi, pendidikan pengelolaan keuangan di keluarga, literasi keuangan.

\section{ABSTRACT}

This study aimed to determine the influence of socioeconomic status and financial management education in the family to the financial literacy in 1 st State Vocational School of Surabaya academic year 2013-2014. Population of this study were 197 students. Sampled by 132 students selected by using simple random sampling. Data were collected by questionnaires and documentation. The method of analysis in this study was regression linear. The results showed that the socioeconomic status of parents directly influence financial literacy, financial management education in the family influence on financial literacy and socioeconomic status also family financial education has significant direct effect on financial literacy

Keywords: Socioeconomic Status, Financial Management Education, Financial Literacy

\section{PENDAHULUAN}

Semakin meningkatnya pertumbuhan perekonomian di dunia, menuntut negara berkembang salah satunya Indonesia untuk lebih melek terhadap keuangan. Sebab Indonesia dinilai menjadi pasar potensial negara maju sebagai tempat untuk melakukan perdagangan internasional. Gaya hidup yang cenderung konsumtif membuat para produsen asing melirik untuk menanamkan usaha di Indonesia. Menurut Lusardi \& Mitchell (2010) bahwa literasi keuangan dapat diartikan sebagai pengetahuan keuangan, dengan tujuan mencapai 
kesejahteraan. Hal ini dapat dimaknai bahwa persiapan perlu dilakukan untuk menyongsong globalisasi (prepare your self), dan lebih spesifiknya yaitu globalisasi dalam bidang keuangan. Cude, Lawrence, Lyons, Metzger, LeJeune, Marks, dan Machtmes (2006) menyatakan bahwa diperlukan pengetahuan tentang bagaimana mengelola keuangan serta bagaimana teknik berinvestasi menjadi hal yang tidak dapat diabaikan lagi seperti waktu-waktu sebelumnya. Lebih jauh, Cude, et. al. (2006) menyatakan bahwa seiring berkembangnya instrumen keuangan, tidak diringi oleh keinginan masyarakat untuk memulai berinvestasi.

Negara Indonesia sebagai negara berkembang dalam pembangunannya membutuhkan sumber daya manusia yang dapat di andalkan dan berkualitas. Sumber daya manusia yang mampu mengelola dan menggunakan bentuk-bentuk variasi keuangan global untuk mencapai kesejahteraan hidup yang lebih baik. Hingga tahun 2013 terakhir, tingkat Indeks Pembangunan Manusia (IPM) atau Human Development Index (HDI) sebesar 0,629\%. Indeks Pembangunan Manusia (IPM) terkait dengan perbandingan dari harapan hidup, melek huruf, perbandingan dan standar hidup untuk semua negara seluruh dunia. Mengenai kualitas sumber daya manusia, pendidikan memiliki peranan penting dalam proses meningkatkan sumber daya manusia. Peningkatan kualitas pendidikan merupakan suatu proses yang integritas dengan proses peningkatan sumber daya manusia.

Selain sekolah tempat untuk belajar mencari pengalaman yang terbaik adalah keluarga. Keluarga memiliki peranan yang cukup besar dalam pembentukan karakter peserta didik. Keluarga merupakan faktor eksternal yang berasal dari luar siswa yang meliputi lingkungan status sosial ekonomi orang tua, peran dan perhatian orang tua terhadap peserta didik. Cenderung peserta didik yang hidup di tengah-tengah keluarga yang mapan, memiliki pendidikan yang tinggi, kecukupan finansial yang lebih, diduga dapat mempengaruhi literasi keuangan peserta didik secara tidak langsung baik dari gaya hidup maupun lingkungan status sosial keluarga. Sehingga bagaimana peran orang tua dalam membentuk karakter peserta didik untuk melek akan keuangan cukup dibutuhkan agar peserta didik akan lebih bijak dalam penggunaanya. Peserta didik menerima pengetahuan dalam hal pengelolaan keuangan secara langsung dari peran serta orang tua dalam mengontrol keuangan pribadi peserta didik. Menurut Wahyono (2001) dalam penelitiannya bahwa tingkat rasionalitas, moralitas, gaya hidup, efektifitas dalam aktivitas produktif, efisiensi dalam konsumtif, dan intensitas pendidikan ekonomi di lingkungan keluarga, secara signifikan berbeda antara kelompok masyarakat dengan status sosial ekonomi rendah, sedang dan tinggi. Dalam pendidikan keuangan tersebut mengandung muatan akan literasi keuangan diantaranya bagaimana peserta didik mampu menyusun skala prioritas dalam penggunaan keuangan dan menginvestasikan sebagian untuk kebutuhan masa depan peserta didik.

Literasi keuangan dapat diartikan sebagai pengetahuan keuangan, dengan tujuan mencapai kesejahteraan. Hal ini dapat dimaknai bahwa persiapan perlu dilakukan untuk menyongsong globalisasi (prepare your self), dan lebih spesifiknya yaitu globalisasi dalam bidang keuangan. Sedangkan Cude, et. al. (2006) menyatakan bahwa diperlukan pengetahuan tentang bagaimana mengelola keuangan serta bagaimana teknik berinvestasi menjadi hal yang tidak dapat diabaikan lagi seperti waktu-waktu sebelumnya. Lebih jauh, Cude, 
et. al. (2006) menyatakan bahwa seiring berkembangnya instrumen keuangan, tidak diringi oleh keinginan masyarakat untuk memulai berinvestasi.

Fenomena yang terjadi di SMK Negeri 1 Surabaya beberapa siswa jurusan akuntansi bahwa peserta didik ketika pulang sekolah lebih suka untuk bermain ke mall sekedar untuk makan, kumpul-kumpul dan bermain. Pemberian uang saku ada sebagian peserta didik diberi orang tuanya perbulan dan ada juga yang harian besarnya sekitar Rp 8.000,- sd Rp 15.000,- per hari. Beberapa peserta didik berasal dari keluarga yang beraneka ragam dari orang tua yang berstatus PNS, Pedagang dan Karyawan swasta dari keseluruhan jumlah peserta didik. Ini merupakan fenomena yang nyata, tidak sedikit ditemukan peserta didik yang masih berseragam sekolah berkunjung ke mall dikarenakan jarak sekolah dengan pusat perbelanjaan sangat dekat. Di antaranya Royal Plasa dan Darmo Trade Center yang berada di Jalan Wonokromo dan Ahmad Yani.

Gaya hidup yang mulai dibiasakan seperti ini dapat memicu rendahnya kesadaran dalam pengelolaan keuangan. Bukti empiris, Lusardi dan Mitchell (2010) menemukan bahwa terdapat perbedaan antara laki-laki dan perempuan dalam membuat keputusan keuangan, dan laki-laki lebih baik karena memiliki pengetahuan keuangan yang lebiih tinggi. Tidak jauh berbeda, Ibrahim, Harun dan Isa (2009) menemukan bahwa mayoritas mahasiswa di Malaysia memiliki pengetahuan keuangan (financial literacy) yang kurang tinggi, dan hal ini dapat menyebabkan tidak terarah dengan tepat pada saat membuat keputusan keuangan setiap hari. Disinilah peran guru dan orang tua dalam menanamkan nilai-nilai literasi keuangan yang didapat disekolah dan lingkungan keluarga agar mampu membendung pola konsumtif peserta didik dalam menentukan skala prioritas kebutuhan.

Pendidikan adalah media sosialisasi pandangan hidup dan kecakapan yang harus diterima masyarakat terutama anak-anak (Soyomukti, 2010). Pendidian sangat berperan penting dalam pembentukan literasi keuangan siswa baik pendidikan formal maupun informal di lingkungan keluarga maupun pendidikan formal di lingkungan perguruan tinggi. Pendidikan keluarga adalah fundamen atau dasar dari pendidikan anak selanjutnya. Pendidikan formal berfungsi melanjutkan pendidikan yang telah dilakukan oleh orang tua di rumah (Purwanto, 2007). Di dalam lingkungan keluarga, tingkat literasi keuangan siswa ditentukan oleh peran orang tua dalam memberikan dukungan berupa pendidikan keuangan dalam keluarga. Keluarga merupakan tempat yang paling dominan dalam proses sosialisasi anak tentang masalah keuangan. Hasil penelitian menunjukan bahwa orang tua mempengaruhi tingkat literasi anak-anak mereka. Pendidikan pengelolaan keuangan di keluarga dikondisikan oleh posisi subkultur dan kelas sosial ekonomi yang pada gilirannya mempengaruhi kognisi dan perilaku mereka. Sesuai dengan penanaman nilai-nilai yang dilakukan orang tua tentang tabungan, kredit, utang, orientasi ke masa depan, kemandirian, strategi pemecahan masalahn keuangan. Dalam penelitian Wahyono (2001) mengungkapkan bahwa tingkat rasionalitas, moralitas, gaya hidup, efektivitas dalam aktifitas produktif, efisiensi dalam aktivitas konsumtif, dan intensitas pendidikan ekonomi di lingkungan keluarga secara signifikan berbeda antara kelompok masyarakat dengan status sosial ekonomi rendah, sedang dan tinggi.

Wahyono (2001) menyatakan bahwa seseorang yang memiliki status sosial lebih tinggi cenderung memiliki wawasan yang lebih luas, lebih mampu meraih 
pendapatan yang lebih besar, dan lebih mampu untuk berinteraksi dengan lingkungan sosialnya dibandingkan dengan seseorang yang berstatus sosial ekonomi rendah. Dengan kelebihan tersebut, wajar apabila antar kelompok status sosial ekonomi memiliki intensitas pendidikan ekonomi dalam lingkungan keluarga yang berbeda. artinya makin tinggi tingkat status sosial ekonomi, makin tinggi intensitas pendidikan ekonomi dalam lingkungan keluarga dan berpengaruh meningkatkan tingkat literasi finansial anak baik secara kognitif maupun sikap.

Bukti empiris, Lusardi dan Mitchell (2010) menemukan bahwa terdapat perbedaan antara laki-laki dan perempuan dalam membuat keputusan keuangan, dan laki-laki lebih baik karena memiliki pengetahuan keuangan yang lebih tinggi. Tidak jauh berbeda, Ibrahim, Harun, dan Isa (2009) menemukan bahwa mayoritas mahasiswa di Malaysia memiliki pengetahuan keuangan (financial literacy) yang kurang tinggi, dan hal ini dapat menyebabkan tidak terarah dengan tepat pada saat membuat keputusan keuangan setiap hari. Disinilah peran guru dan orang tua dalam menanamkan nilai-nilai literasi keuangan yang didapat disekolah dan lingkungan keluarga agar mampu membendung pola konsumtif peserta didik dalam menentukan skala prioritas kebutuhan.

Pada penelitian sebelumnya yang dilakukan oleh Irin (2011) menyebutkan variabel yang diduga mempengaruhi literasi keuangan yaitu status sosial ekonomi, pendidikan pengelolaan keuangan keluarga dan cara pendidikan pengelolaan keuangan di keluarga berpengaruh signifikan terhadap literasi keuangan. Pada penelitian yang dilakukan oleh Jorgensen (2010) yang mengungkapkan bahwa variabel status sosial ekonomi tidak berpengaruh pada pengetahuan keuangan siswa karena tinggi rendahnya status sosial yang dimiliki tidak menjamin seseorang memiliki pemahaman keuangan yang tinggi, yang lebih penting dan mempengaruhi literasi keuangan siswa adalah peran orang tua dalam memberikan pendidikan keuangan di lingkungan keluarga. Sehingga penemuan ini akan memperkuat penelitian sebelumnya atau peneliti akan menemukan hasil yang berbeda dengan objek dan sampel yang berbeda.

Mengingat bahwa variabel status ekonomi sosial orang tua selalu berbeda disetiap sekolah, pendidikan pengelolaan keuangan keluarga memiliki karakteristik yang berbeda pula memungkinkan akan muncul temuan baru yang manarik untuk diteliti kembali di SMK Negeri 1 Surabaya. Apakah variabel status sosial ekonomi dan pendidikan pengelolaan keuangan di keluarga berpengaruh secara signifikan terhadap literasi keuangan baik secara sebagai variabel intervening antara status sosial ekonomi dengan pendidikan pengelolaan keuangan di keluarga maupun parsial. Penelitian ini akan menghasilkan penelitian baru dengan menguji varibale status sosial ekonomi dengan pendidikan keuangan di keluarga sebagai variabel intervening serta karakteristik obyek dan sampel yang berbeda di setiap penelitian yang sudah dilakukan. Menurut Remund (2010) menyatakan empat hal yang paling umum dalam literasi finansial adalah penganggaran, tabungan, pinjaman dan Investasi. Dari pengertian beberapa ahli bahwa literasi keuangan memiliki empat indikator diantaranya penganggaran, pinjaman, tabungan dan investasi. Apabila dari keempat indikator itu dimiliki oleh peserta didik maka literasi keuangan dari peserta didik dikatakan sadar atau melek akan keuangan. Sehingga ke empat indikator tersebut dapat dijadikan tolok ukur tingkat literasi keuangan siswa SMK Negeri 1 Surabaya. Indikator dari literasi 
keuangan apabila seorang siswa mampu secara maksimal memaksimalkan potensi penganggaran, tabungan, pinjaman dan investasi.

Terkait dengan status sosial ekonomi orangtua, Bahrein menyatakan bahwa status cenderung merujuk pada kondisi ekonomi dan sosial seseorang dalam kaitannya dengan jabatan atau kekuasaan dan peranan yang dimiliki orang bersangkutan di dalam masyarakat. Status cenderung memperlihatkan tingkat kedudukan seseorang dalam hubungannya dengan status orang lain berdasarkan suatu ukuran tertentu. Ukuran atau tolok ukur yang dipakai didasarkan pada salah satu atau kombinasi yang mencakup tingkat pendapatan, pendidikan, prestise atau kekuasaan (Bahrein, 1996). Menurut Owen (2003) menyatakan bahwa untuk memiliki ketrampilan mengelola keuangan dengan baik, paling tidak anak harus dilatih dalam hal menabung, mengelola uang saku, melakukan pekerjaan ringan di luar rumah, berderma dan berinvestasi.

Beberapa penelitian terdahulu diantaranya adalah Khrisna (2008), yang menyebutkan bahwa mahasiswa UPI jauh dari optimum bahkan mendekati kategori rendah sehingga harus ditingkatkan lagi terutama yang berkaitan dengan pengetahuan investasi, kredit dan asuransi. Selain itu hasil demografi seperti jenis kelamin, usia, asal program studi dan pengalaman kerja mempengaruhi tingkat literasi finansial responden. Jorgensen (2010) menyimpulkan bahwa tidak ada perbedaan yang berarti literasi keuangan berdasarkan jenis kelamin, peringkat kelas dan Status sosial ekonomi. Terdapat perbedaan berdasar tingkat peran orang tua dan teman sebaya memiliki pengaruh signifikan terhadap literasi keuangan.

Menurut Sina (2010) Secara keseluruhan dari ke empat bentuk literasi keuangan, hanya bentuk pengetahuan umum yang relatif baik sedangkan bentuk lainnya menunjukkan bahwa literasi keuangan dosen-dosen muda UKSW berada pada tingkatan rendah. Sedangkan jenis kelamin memiliki peranan penting bahwa laki-laki memiliki tingkat literasi yang rendah. Sedangkan menurut Nababan (2011) Berdasarkan tingkat pendapatan dan tingkat pendidikan orang tua responden, tingkat literasi keuangan tidak meningkat secara konsisten seiring dengan peningkatan pendidikan dan pendapatan orang tua. Sedangkan hasil analisis deskriptif berdasarkan jenis kelamin menunjukkan bahwa laki-laki cenderung memiliki tingkat personal financial literacy yang lebih tinggi. Mayasari (2011) menyimpulkan bahwa pembelajaran mata pelajaran ekonomi mempunyai pengaruh yang signifikan terhadap perilaku konsumsi siswa kelas XI IPS SMA Negeri 1 Surabaya.

Rahman (2011) menyimpulkan faktor - faktor yang mempengaruhi literasi keuangan diantarannya peran orang tua, pendapatan, pendidikan dan pendapatan orang tua. Sedangkan jenis kelamin, umur dan pendidikan keuangan di kelas / formal tidak berpengaruh secara signifikan.Widayati (2012) bahwa Berdasarkan hasil analisis data, diperoleh kesimpulan: (1) status sosial ekonomi orang tua berpengaruh langsung positif signifikan terhadap pendidikan pengelolaan keuangan keluarga; (2) status sosial ekonomi orang tua tidak berpengaruh langsung terhadap literasi finansial aspek kognitif; (3) status sosial ekonomi orang tua tidak berpengaruh langsung terhadap literasi finansial aspek sikap; (4) pendidikan pengelolaan Irin Widayati: Faktor-Faktor yang Mempengaruhi Literasi Financial. Keuangan keluarga berpengaruh langsung positif signifikan terhadap literasi finansial aspek kognitif; (5) pendidikan pengelolaan keuangan keluarga berpengaruh langsung positif signifikan terhadap literasi finansial 
aspek sikap; (6) pembelajaran di perguruan tinggi berpengaruh langsung positif signifikan terhadap literasi finansial aspek kognitif; (7) pembelajaran di perguruan tinggi berpengaruh langsung positif signifikan terhadap literasi finansial aspek sikap; (8) status sosial ekonomi orang tua berpengaruh tidak langsung positif signifikan terhadap literasi finansial aspek kognitif yang dimediasi oleh pendidikan pengelolaan keuangan keluarga; (9) status sosial ekonomi orang tua berpengaruh tidak langsung positif signifikan terhadap literasi finansial aspek sikap yang dimediasi oleh pendidikan pengelolaan keuangan keluarga.

Sapariah (2013) menyimpulkan bahwa hasil penelitian dengan kondisi ekonomi orang tua, pendidikan ekonomi di lingkungan keluarga, dan apresiasi orang tua berpengaruh terhadap hasil belajar siswa sebesar 60,9\%. Sedangkan menurut Wahyono (2001) menyimpulkan dari penelitian ini adalah tingkat rasionalitas, moralitas, gaya hidup, efektivitas dalam aktivitas produksi, efisiensi dalam aktivitas konsumsi, dan intensitas pendidikan ekonomi dilingkungan keluarga secara signifikan berbeda antara kepala keluarga dengan status sosial ekonomi rendah, sedang, dan tinggi. Fowdar (2007) menyimpulkan dari hasil penelitian bahwa jenis kelamin, kelompok umur, pendidikan, status sosial ekonomi dan tingkat pendapatan orang tua berpengaruh signifikan terhadap literasi keuangan. Menurut Lusardi, et. al. (2010) mengambil kesimpulan dalam penelitian yaitu pendidikan orang tua mempengaruhi secara signifikan terhadap literasi keuangan anak. Sedangkan Cude, et. al. (2006) menyimpulkan dari penelitianyaitu ditemukan bahwa orang tua memiliki peranan penting dalam memberikan sosialisasi pengetahuan keuangan terhadap anak.

\section{METODE PENELITIAN}

Metode penelitian ialah teknik atau сага yang ditempuh oleh peneliti dalam melakukan penelitian. Teknik atau cara yang dilakukan antara lain menentukan tempat, alokasi waktu, sasaran penelitian, dan dilanjutkan dengan sunan rancangan penelitian, teknik pengumpulan data dan teknik analisis data. Jenis penelitian ini adalah pendekatan kuantitatif. Penelitian Kuantitatif adalah penelitian yang ilmiah yang sistematis terhadap bagian-bagain dan fenomena serta hubungan-hubungannya. Tujuan Penelitian Kuantitatif adalah mengembangkan dan menggunakan model-model matematis, teori-teori dan hipotesis yang dikaitkan dengan fenomena alam.

Literasi keuangan (Y) dapat diartikan sebagai pengetahuan dengan tujuan untuk mencapai kesejahteraan. Sedangkan Status sosial ekonomi (X1) adalah ukuran gabungan dari posisi ekonomi dan sosial individu atau keluarga yang relatif terhadap orang lain, berdasarkan dari pendapatan, pendidikan, dan pekerjaan dan pendidikan pengelolaan keuangan di keluarga (X2) merupakan tempat yang paling dominan dalam proses sosialisasi tentang masalah keuangan. Melalui pendidikan keluarga, dengan cara-cara sederhana anak dibawa ke suatu sistem nilai atau sikap hidup yang diinginkan dan disertai teladan orang tua yang secara tidak langsung sudah membawa anak kepada pandangan dan kebiasaan tertentu.

Populasi penelitian adalah wilayah generalisasi yang terdiri atas objek/subjek yang mempunyai kualitas dan karakteristik tertentu yang ditetapkan 
oleh peneliti untuk dipelajari dan kemudian ditarik kesimpulannya. Populasi penelitian adalah siswa kelas XI AK SMK Negeri 1 Surabaya yang memilih Program Studi Akuntansi tahun ajaran 2013-2014 sejumlah 197 siswa. Sampel adalah bagian dari jumlah dan karakteristik yang dimiliki oleh populasi tersebut. Sampel yang diambil dari populasi harus betul-betul representatif. Teknik sampling yang peneliti ambil adalah teknik proportional random sampling yaitu teknik pengambilan sampel yang memberikan peluang yang sama bagi setiap unsur populasi untuk dipilih menjadi anggota sampel atau setiap elemen mempunyai kemungkinan atau peluang yang sama untuk dipilih sebanyak 132 sampel yang diambil.

Tabel 1.

\section{Indikator Variabel Penelitian}

\begin{tabular}{|l|l|l|l|}
\hline No. & \multicolumn{1}{|c|}{ Variabel } & \multicolumn{1}{|c|}{ Indikator } & \multicolumn{1}{c|}{ Sumber } \\
\hline 1 & Literasi Keuangan & $\begin{array}{l}\text { a. Penganggaran } \\
\text { b. Investasi } \\
\text { c. Tabungan } \\
\text { d. Pinjaman }\end{array}$ & $\begin{array}{l}\text { Remund } \\
(2010)\end{array}$ \\
\hline 2 & Status Sosial Ekonomi & $\begin{array}{l}\text { a. Pendapatan } \\
\text { b. Pendidikan } \\
\text { c. Pekerjaan }\end{array}$ & $\begin{array}{l}\text { Bahrein } \\
(1996)\end{array}$ \\
\hline 3 & Pendidikan Pengelolaan & $\begin{array}{l}\text { a. Kebiasaan menabung } \\
\text { b. Melakukan pembayaran secara } \\
\text { Keuangan Keluarga }\end{array}$ & $\begin{array}{l}\text { mandiri atas kebutuhan tambahan } \\
\text { mereka }\end{array}$ \\
& & $\begin{array}{l}\text { c. Mengelola uang saku } \\
\text { d. Mencari pekerjaan ringan di luar } \\
\text { rumah }\end{array}$ & \\
\hline
\end{tabular}

Ada beberapa pengumpulan data yang digunakan dalam penelitian ini adalah metode kuisioner, metode wawancara, dan metode dokumentasi. Kuisioner diberikan kepada responden, yaitu siswa program studi akuntansi tahun ajaran 2013-2014 di SMK Negeri 1 Surabaya pada bulan Mei 2014 di lingkungan SMK Negeri 1 Surabaya. Dalam penyebaran kuesioner, peneliti melakukan kontak langsung dengan responden sehingga diharapkan responden dengan sukarela akan memberikan data yang objektif dan cepat, mengisi kuisioner dengan jawaban yang sesungguhnya, serta untuk memastikan kuesioner kembali kepada peneliti dan meminimalkan tingkat ketidakkembalian kuesioner. Wawancara dilakukan untuk mendapatkan data secara langsung dari responden. Dari hasil wawancara, penelitian ini akan lebih peka terhadap jawaban-jawaban yang disampaikan oleh responden sehingga tingkat kesalahan dalam jawaban akan kecil karena penelitian ini akan bertatap muka secara one by one dengan responden. Wawancara merupakan faktor pendukung untuk kuesioner. Penelitian ini menggunakan metode dokumentasi dengan tujuan untuk merekam hasil penelitian di lapangan dalam bentuk kajian dokumen-dokumen sekolah yaitu jumlah siswa, pekerjaan orang tua, penghasilan orang tua, susunan struktur sekolah hingga perangkat pembelajaran yang digunakan di sekolah. 
Pengujian ini dilakukan agar regresi ganda yang digunakan layak dipakai untuk memprediksi variabel. Menurut Ghozali (2005) uji asumsi klasik adalah sebagai berikut: a) Uji Normalitas : Pengujian ini digunakan untuk menguji apakah dalam sebuah model regresi, variabel dependen dan variabel mempunyai distribusi normal atau tidak. Data terdistribusi dengan baik bila terlihat titik menyebar disekitar garis diagonal, serta penyebarannya mengikuti arah garis diagonal uji normalitas. Hal tersebut menunjukkan pola distribusi normal. Untuk menentukan data dengan uji Kolmogrov-Smirnov, nilai signifikan diatas 0,050 atau 5\% (Ghozali, 2005). b) Uji Multikolinieritas : Uji multikolinieritas diperlukan untuk mengetahui ada tidaknya variabel independen yang mempunyai kemiripan dengan variabel independen lain dalam satu model. Regresi yang baik jika tidak terjadi multikolinieritas. Pengujian Multikolinieritas ini dapat dilihat dari nilai variance inflation factor (VIF) Antara variabel bebas dikatakan multikolinieritas apabila toleransinya $<0,1$ dan VIF $>10$. c) Uji Heteroskedastisitas : Model regresi yang baik adalah jika terjadi homokedastisitas atau tidak terdapat heteroskedastisitas. Uji heteroskedastisitas bertujuan untuk menguji apakah dalam model regresi terjadi ketidaksamaan varian dari residual satu pengamatan ke pengamatan yang lain. Jika varian dari residual satu pengamatan ke pengamatan lain tetap, maka dapat disebut homoskedastisitas dan jika berbeda disebut heteroskedastisitas. d) Uji Linieritas : Uji linieritas merupakan prosedur yang digunakan untuk mengetahui status linier atau tidaknya suatu distribusi data penelitian, atau dikatakan apakah antara variabel bebas dan variabel terikat tersebut linier. Teknik yang digunakan untuk mengujinya yaitu dengan menggunakan curve fit dan tabel anova. Bila $\mathrm{p}$ linieritas $<0.05$ dapat dikatakan linier, maka variabel bebas termasuk layak sebagai salah satu prediktor variabel terikat (Y), demikian juga sebaliknya.

\section{HASIL DAN PEMBAHASAN}

Analisis dalam penelitian ini menggunakan analisis regresi berganda yang berfungsi untuk mengetahui ada tidaknya pengaruh antara ketiga variabel yaitu variabel status sosial ekonomi $\left(\mathrm{X}_{1}\right)$, pendidikan pengelolaan keuangan di keluarga $\left(\mathrm{X}_{2}\right)$ terhadap literasi keuangan $(\mathrm{Y})$. Untuk mengetahui variabel bebas terhadap variabel terikat dilakukan analisis regresi linier berganda dengan persamaan regresi sebagai berikut: $\mathrm{Y}=1.223+1.272 \mathrm{X}_{1}+0.346 \mathrm{X}_{2}+$ e. Dari persamaan regresi linier linier berganda tersebut diketahui nilai konstanta $(\alpha)$ sebesar 1.223 artinya bahwa dengan menganggap semua variabel bebas sama dengan 0 , maka literasi keuangan dalam kondisi positif dengan nilai 1.223. Koefisien Motivasi belajar intrinsik $\left(b_{1}\right)$ sebesar 1.272 artinya bahwa setiap peningkatan satu persen status sosial ekonomi pada literasi keuangan akan mengalami peningkatan sebesar 1.272 persen. Dalam hal ini faktor lain yang mempengaruhi literasi keuangan dianggap tetap. Koefisien regresi gaya belajar $\left(b_{2}\right)$ sebesar 0,346 artinya bahwa setiap peningkatan satu persen pendidikan pengelolaan keuangan pada siswa maka literasi keuangan akan mengalami peningkatan sebesar 0,346 persen. Dalam hal ini faktor lain yang mempengaruhi literasi keuangan dianggap tetap.

Uji $t$ statistik digunakan untuk mengetahui pengaruh masing-masing variabel bebas terhadap variabel terikat yaitu pengaruh secara parsial status sosial ekonomi dan pendidikan pengelolaan keuangan di keluarga terhadap literasi 
keuangan siswa kelas XI Akuntansi SMK Negeri 1 Surabaya, maka pada penelitian ini dilakukan uji t. Dapat dilihat bahwa nilai signifikansi masingmasing variabel bebas di mana variabel $\mathrm{X}_{1}$ status sosial ekonomi memiliki $\mathrm{t}_{\text {itung }}=$ $19,911>1,976$ signifikansi $(\mathrm{sig})=0,000<$ taraf signifikansi $\alpha=0,05$, maka dapat disimpulkan bahwa ada pengaruh yang positif dan signifikan status sosial ekonomi terhadap literasi keuangan siswa kelas XI Akuntansi SMK Negeri 1 Surabaya. Hal ini berarti bahwa status sosial ekonomi secara parsial berpengaruh signifikan positif terhadap literasi keuangan siswa sehingga hipotesis ke-1 penelitian ini diterima.

Dari penelitian yang dilakukan oleh Lusardi (2010) yang menyatakan bahwa tingkat literasi seseorang dipengaruhi oleh tingkat pekerjaan orang tua. Sedangkan menurut penelitian Gutter (2008) menyatakan bahwa siswa yang mempunyai status sosial ekonomi yang tinggi juga mempunyai tingkat pengetahuan, sikap, dan perilaku keuangan yang tinggi. Menurut Bahrein (1996) status sosial ekonomi cenderung merujuk pada kondisi ekonomi dan sosial seseorang dalam kaitannya dengan jabatan (kekuasaan) dan peranan yang dimiliki orang bersangkutan di dalam masyarakat. Status cenderung memperlihatkan tingkat kedudukan seseorang dalam hubungannya dengan status orang lain berdasarkan suatu ukuran tertentu.

Secara teori, tingkat pendidikan orang tua yang tinggi dan pendapatan ekonomi orang tua yang mencukupi dapat meningkatkan literasi finansial siswa. Sebaliknya siswa SMK Negeri 1 Surabaya dengan status sosial ekonomi orang tua yang rendah relatif memiliki literasi finansial yang rendah pula. Adanya keterkaitan yang erat ini dipengaruhi oleh ketersediaan sarana belajar siswa. Orang tua yang memiliki pendapatan yang tinggi dapat memfasilitasi anaknya untuk mengembangkan bermacam kecakapan yang tidak dapat dia perkembangkan apabila tidak ada alatnya. Menurut Ahmadi (2007) keadaan sosial ekonomi keluarga berperan terhadap perkembangan anak. Misalnya anak yang orang tuannya berpenghasilan cukup mendapatkan lebih banyak kesempatan untuk mengembangkan bermacam kecakapan, dan begitu pula sebaliknya.

Secara empiris ternyata ditemukan bahwa status sosial ekonomi orang tua berpengaruh langsung positif terhadap literasi keuangan. Pengembangan literasi keuangan sangat terkait dengan aktifitas yang dilakukan seseorang yang berhubungan dengan penggunaan uang. Latar belakang orang tua, pekerjaan orang tua dan jabatan sosial orang tua dapat mempengaruhi sikap seseorang dalam melakukan kegiatan belanja, menabung, investasi, kredit, penganggaran, dan pengelolaan keuangan. Menurut Ahmadi (2007) mengungkapkan bahwa status sosial ekonomi orang tua mempunyai pengaruh terhadap tingkah laku dan pengalaman anaknnya.

Berdasarkan hasil penelitian ini mendukung teori tersebut dan hal ini disebabkan karena beberapa hal. Keluarga berpenghasilan rendah akan fokus pada pemenuhan kebutuhan yang mendesak dan tidak menumpuk kekayaan yang dapat diteruskan oleh generasi yang akan datang, sehingga meningkatkan ketimpangan. Menurut Boushey (2005) yaitu keluarga dengan pendapatan yang lebih tinggi dan mengeluarkan uang dapat mengumpulkan kekayaan dan fokus pada pemenuhan mendesak. Pendidikan tinggi orang tua akan mendorong siswa untuk lebih melek akan keuangan dalam hal ini pemberiaan uang saku dan penggunaan uang saku secara tepat. Cenderung orang tua yang memiliki background pendidikan tinggi 
akan lebih concern dalam mengontrol keuangan anak, mendidik anak lebih tanggung jawab terhadap uang saku yang diberi, pemberian pendidikan keuangan secara tidak langsung dengan pengelolaan keuangan mandiri, pembayaran listrik dan air dalam proses melibatkan anak.

Sehingga dapat disimpulkan bahwa siswa yang memiliki status sosial ekonomi orang tua yang tinggi cenderung siswa memiliki literasi yang tinggi karena mampu mengelola keuangan pribadi yang di control oleh orang tua yang memiliki pendidikan, pekerjaan dan pendapatan yang tinggi. Sebaliknya siswa yang memiliki status sosial ekonomi rendah cenderung mereka tidak sempat fokus dalam hal pengelolaan keuangan karena siswa akan cenderung fokus terhadap kebutuhan yang mendesak tidak ada proses menumpuk kekayaan yang sifatnya jangka panjang dan keterbatasaan ekonomi yang memicu rendahnya akan pengetahuan literasi keuangan siswa.

Variabel $\mathrm{X}_{2}$ pendidikan pengelolaan keuangan di keluarga memiliki $t_{\text {hitung }}=$ $5,515>1,976$ signifikansi $(\mathrm{sig})=0,000<$ taraf signifikansi $\alpha=0,05$ maka dapat disimpulkan bahwa ada pengaruh yang positif dan signifikan pendidikan pengelolaan keuangan di keluarga terhadap literasi keuangan siswa kelas XI Akuntansi SMK Negeri 1 Surabaya. Hal ini berarti bahwa pendidikan pengelolaan keuangan di keluarga secara parsial berpengaruh signifikan positif terhadap literasi keuangan siswa sehingga hipotesis ke-2 penelitian ini diterima.

Temuan ini sejalan dengan hasil penelitian sebelumnya yang dilakukan oleh Jorgensen (2007) yang menyatakan bahwa siswa yang belajar banyak tentang mengelola keuangan pada orang tuanya memiliki pengetahuan keuangan yang lebih tinggi daripada siswa yang tidak belajar tentang mengelola keuangan pada orang tuannya. Penelitian oleh Cude, et. al. (2006) menyatakan bahwa orang tua memainkan peranan yang sangat penting dalam proses sosialisasi keuangan anak mereka.

Keluarga merupakan tempat yang paling dominan dalam proses sosialisasi anak tentang masalah keuangan. Proses pendidikan yang meliputi mental, fisik dan intelektual di lingkungan keluarga dapat berlangsung terus hingga anak dewasa. Melalui keteladanan, siswa mengamati apa yang diperbuat oleh orang tuannya. Dalam perspektif teori belajar sosial oleh Bandura (Ahmadi, 2007) sebagian besar tingkah laku individu diperoleh dari hasil belajar melalui pengamatan atas tingkah laku yang ditampilkan oleh individu lain menjadi model. Pengetahuan dan kepribadian seseorang berkembang melalui proses pengamatan, dimana orang belajar melalui observasi terhadap perilaku orang lain terutama pemimpin atau orang yang dianggap mempunyai nilai lebih dari orang lainnya.

Siswa belajar melalui keterlibatan secara langsung dalam aktivitas keuangan keluarga. Pengalaman adalah guru yang terbaik. Pengalaman yang didapatkan siswa dari pengalaman belajar langsung lebih mudah dicerna dan terekam dalam memorinya. Sesua dengan teori yang diungkap oleh Schaefer (1996) bahwa melatih kecakapan anak termasuk mengajak anak untuk mempraktikan dan memperoleh ketrampilan yang diperlukan untuk menghadapi masalah sehari-hari secara efektif dan dapat memanfaatkan kesempatan yang timbul.

Gaya hidup yang konsumtif akan cenderung mudah ditiru oleh anak dalam kehidupan sehari-hari. Orang tua merupakan alat untuk pengendali anak dalam mengelola keuangan. Menurut Owen (2003) menyatakan bahwa untuk memiliki ketrampilan mengelola keuangan dengan baik, paling tidak anak harus dilatih 
dalam hal menabung, mengelola uang saku, melakukan pekerjaan ringan diluar rumah, berderma dan berinvestasi.

Pengetahuan siswa juga dibangun dari pelaksanaan diskusi dengan keluarga terkait masalah keuangan. Seeperti yang diungkap Jorgensen (2007) bahwa diskusi secara langsung dengan keluarga mengenai pengelolaan uang akan meningkatkan pengetahuan dan pembentukan sikap, nilai dan perilaku anak anak. Demikian secara teoritis temuan penelitian yang menyatakan bahwa pendidikan pengelolaan keuangan keluarga berpengaruh terhadap literasi keuangan aspek kognitif terbukti pada siswa SMK Negeri 1 Surabaya.

Dari hasil nilai $F_{\text {hitung }}$ sebesar 1713,435 dengan nilai signifikan kurang dari $5 \%$ yaitu 0,000. Maka dapat disimpulkan bahwa status sosial ekonomi dan pendidikan pengelolaan keuangan di keluarga secara simultan berpengaruh signifikan positif terhadap literasi keuangan siswa sehingga hipotesis ke-3 penelitian ini diterima..

Hasil dari penelitian ini menunjukan bahwa status sosial ekonomi orang tua dan pendidikan pengelolaan keuangan keluarga memiliki pengaruh yang positif signifikan terhadap literasi keuangan pada siswa SMK Negeri 1 Surabaya. Penelitian ini membuktikan bahwa status sosial ekonomi orang tua terbukti berpengaruh terhadap literasi keuangan bila variabel tersebut dikaitkan dengan pendidikan pengelolaan keuangan keluarga.

Orang tua yang memiliki pendidikan yang lebih tinggi memang memiliki sumber daya berupa pendapatan, waktu, tenaga, dan jaringan kontak yang cenderung lebih besar. Hal ini memungkinkan mereka untuk terlibat dalam lebih jauh dalam pendidikan anak. Orang tua dengan tingkat pendidikan yang lebih tinggi juga memungkinkan untuk lebih percaya diri pada kemampuan mereka dalam membantu anak mereka belajar. Dengan tingkat keyakinan tersebut maka diperkirakan akan berpengaruh secara siginifikan terhadap kemampuan anak.

Wahyono (2001) menyatakan bahwa seseorang yang memiliki status sosial lebih tinggi cenderung memiliki wawasan yang lebih luas, lebih mampu meraih pendapatan yang lebih besar, dan lebih mampu untuk berinteraksi dengan lingkungan sosialnya dibandingkan dengan seseorang yang berstatus sosial ekonomi rendah. Dengan kelebihan tersebut, wajar apabila antar kelompok status sosial ekonomi memiliki intensitas pendidikan ekonomi dalam lingkungan keluarga yang berbeda. artinya makin tinggi tingkat status sosial ekonomi, makin tinggi intensitas pendidikan ekonomi dalam lingkungan keluarga dan berpengaruh meningkatkan tingkat literasi finansial anak baik secara kognitif maupun sikap.

Dengan semakin tinggi status sosial ekonomi orang tua, makin besar kesempatan siswa untuk memperoleh pengalaman belajar dalam kehidupan yang berkaitan dengan aspek keuangan (Ahmadi, 2007). Dengan adanya pendidikan pengelolaan keuangan keluarga, pengalaman-pengalaman siswa menjadi bermakna sehingga berkontribusi dalam meningkatkan pengetahuan dasar keuangan siswa.

\section{SIMPULAN}

Berdasarkan hasil penelitian, dapat ditarik simpulan bahwa status sosial ekonomi orang tua berpengaruh secara langsung positif signifikan terhadap literasi keuangan siswa kelas XI Akuntansi SMK Negeri 1 Surabaya. Artinya semakin 
tinggi status sosial ekonomi orang tua berpengaruh terhadap tingginya literasi keuangan siswa. Demikian sebaliknya semakin rendah status sosial ekonomi akan berpengaruh terhadap semakin kurangnya literasi keuangan. Pendidikan pengelolaan keuangan di keluarga juga berpengaruh secara langsung positif signifikan terhadap literasi keuangan siswa kelas XI Akuntansi SMK Negeri 1 Surabaya. Artinya bahwa tinggi atau rendahnya pendidikan pengelolaan keuangan di keluarga berpengaruh terhadap literasi keuangan secara langsung. Status sosial ekonomi orang tua berpengaruh secara langsung positif signifikan terhadap pendidikan pengelolaan keuangan di keluarga siswa kelas XI Akuntansi SMK Negeri 1 Surabaya. Artinya semakin tinggi status sosial ekonomi orang tua berpengaruh terhadap pendidikan pengelolaan keuangan di keluarga. Demikian sebaliknya apabila status sosial ekonomi rendah maka pendidikan pengelolaan keuangan di keluarga akan rendah pula. Status sosial ekonomi orang tua berpengaruh secara langsung signifikan terhadap literasi keuangan bersama pendidikan pengelolaan keuangan siswa kelas XI Akuntansi SMK Negeri 1 Surabaya. Artinya status sosial ekonomi orang tua dengan pendidikan pengelolaan keuangan keluarga memiliki pengaruh yang positif signifikan terhadap literasi keuangan siswa.

\section{DAFTAR RUJUKAN}

Ahmadi, A., 2007. Psikologi Sosial. Jakarta: Rineka Cipta.

Astuti, 2012. "Pengaruh Kemandirian belajar dan penggunaan uang saku terhadap prestasi belajar kompetensi dasar ekonomi kelas VII dan VIII". Vol 1 No 2. Journal. Unnes.ac.id

Bahrein, T. Sugihen, 1996.Sosiologi Pedesaan.Jakarta: Rajawali Press

Boushey, Heather, \& Weller, Christian, 2005. Inequality Matters: The Growing Economic Divide in America and its Poisonous Consequences.. "What the Numbers Tell Us." Vol. 47 No 2 Pp 27-40. Demos.

Cude, et. al., 2006. Collage Student and Financial Literacy: What They Know and What We Need to Learn. Eastern Family Economic and Resource Managemen Association.

Ibrahim, D, Harun, R. \& Isa, Z. M., (2009). A Study on Financial Literacy of Malaysian Degree Students. Cross-cultural Communication ISSN 17128358 Vol.5 No.4 2009

Irin W,. 2011. Pengaruh Status Sosial Orang Tua. Pendidikan pengelolaan Keuangan di Keluarga dan Pembelajaran Akutansi di Perguruan Tinggi terhadap Literasi Finansial Mahasiswa Unibraw. Tesis tidak diterbitkan. Malang PPS UM.

Jorgensen, E. \& Margaret SS., 2010. From Financial to Financial Capibility among The Young. Journal of Sociologi and Social Welfare 34.

Khrisna, Ayu, 2008. Analisis Tingkat Literasi Keuangan di Kalangan Mahasiswa dan Faktor - faktor yang Mempengaruhinya ( Survey Pada Mahasiswa Universitas Pendidikan Indonesia ). Malang

Lusardi, et. al, 2010. Financial Literacy Among The Young. Journal of Consumer Affairs Volume 44 Issue 2.

Owen, D., 2003. Melejitkan kecerdasan Finansial Anak. Terjemahan Lovely. Bandung: Kaifa. 
Susanti, 2013. "Faktor-faktor yang mempengaruhi Literasi Keuangan Mahasiswa Fakultas Ekonomi Universitas Negeri Surabaya". Jurnal Ekonomi Bisnis. ISSN 0853-7283. Thn 18 No 1 Maret 2013. Pp 89-96

Remund, D L., 2010. Financial literacy explicated: the case for a clearer definition in an increasingly complex economy. Journal of Consumer Affairs Volume 44 Issue 2.

Sina, Peter, et. al., 2010. Perbedaan antara faktor jenis kelamin terkait literasi keuangan untuk bentuk pengetahuan umum, tabungan, asuransi dan investasi. Global Network Jurnal - Vol. 5 No. 2 August 2012. Pp 230-251

Wahyono, H., 2001. Pengaruh Perilaku Ekonomi Kepala Keluarga terhadap Intensitas Pendidikan Ekonomi di Lingkungan Keluarga. Disertasi tidak diterbitkan. Malang: PPs UM

Warsono, 2010. Prinsip-prinsip dasar dan Keuangan Pribadi. Jurnal salam. Volume 13 Nomer 2 Juli - Desember 2010

Widayati, Irin, 2012. Faktor - faktor Yang Mempengaruhi Literasi Finansial Mahasiswa Fakultas Ekonomi dan Bisnis Universitas Brawijaya. Jurnal akuntansi dan pendidikan. Vol. 1 no. 1 okt 2012 